\title{
EVALUATION OF BULLYING IN PERSONS WITH DIFFERENT RISK FOR PSYCHOSIS
}

\author{
Jelena Vasić ${ }^{1}$, Sanja Andrić1, Nađa Marić Bojović \\ ${ }^{1}$ Faculty of Medicine, University of Belgrade, Serbia \\ ${ }^{2}$ Mentor: Faculty of Medicine, University of Belgrade, Serbia; Clinic for Psychiatry, Clinical Center of Serbia \\ Contact e-mail: eleni.eev92@yahoo.com
}

Sažetak

Uvod: Novija istraživanja pokazuju da bi izloženost vršnjačkom maltretiranju tokom detinjstva mogla biti povezana sa povećanim rizikom za psihotična iskustva u odraslom dobu. Poznato je i da su dečaci skloniji da učestvuju u vršnjačkom maltretiranju, tj. da se češće se nalaze i u ulozi žrtve, ali i ulozi agresora.

Cilj: Istražiti da li je učestalost maltretiranja veća među pacijentima sa psihozom u kliničkoj populaciji Srbije, u poređenju sa njihovim zdravim srodnicima i sa kontrolnom grupom opšte populacije, i analizirati razlike među polovima u domenu vršnjačog maltretiranja.

Materijal i metode: Studijom su bili obuhvaćeni pacijenti sa dijagnozom iz shizofrenog spektra $(n=52$, starost $=29,3 \pm 5,9$ godina, u remisiji, trajanje bolesti $<10$ godina), njihovi zdravi srodnici $(\mathrm{n}=55$, starost $=28,6 \pm$ 6,8 godina) i kontrole $(\mathrm{n}=50$, starost $=25,3 \pm 1,5$ godina). Za analizu podataka korišćeni su deskriptivna statistika i Mann-Whitney neparametarski test.

Rezultati: U poređenju sa zdravim srodnicima, pacijenti su češće bili maltretirani (pacijenti: 7,0 $\pm 3,5$, rođaci: $5,2 \pm 2,0, p=0,000$ ), međutim, oni su bili skloniji i tome da maltretiraju druge (pacijenti: $1,4 \pm 0,8$, rođaci: $1,1 \pm 0,4, p=0,02)$. Poredeći grupu pacijenata i kontrola, nije pronađena značajna razlika ni u jednoj ispitivanoj kategoriji. Muški pol nosi veći rizik od fizičkog maltretiranja, što je dokazano za sve ispitivane grupe (pacijenti$\mathrm{p}=0.03$, kontrole i rođaci- $\mathrm{p}=0,00$ ).

Zaključak: Uzevši u obzir da je vršnjačko zlostavljanje bilo češće u grupi pacijenata u odnosu na njihove zdrave rođake, može se zaključiti da ono može imati određeni uticaj na razvoj psihoze. Prevencija maltretiranja i tretman psiholoških posledica istog mogli bi biti jedan od načina da se utiče na etiopatogenezu psihotičnih poremećaja.

Ključne reči: vršnjačko zlostavljanje, psihoza, mentalno zdravlje, pol
Abstract

Introduction: Emerging research suggests that being exposed to bullying during childhood can increase the risk of psychotic experiences in adulthood. Aggressive peer relations among adolescents are more frequent in boys, both for being victims or perpetrators.

Aim: To evaluate whether bullying was more prevalent among Serbian clinical population of patients with psychosis in comparison to their healthy siblings and controls, and to analyze gender differences regarding bullying.

Material and methods: This cross-sectional study evaluated schizophrenia spectrum patients $(\mathrm{n}=52$, age $=29.3 \pm 5.9 \mathrm{yrs}$, in remission, illness duration $<10$ yrs $)$, their healthy siblings $(n=55$, age $=28.6 \pm 6.8$ yrs) and controls ( $\mathrm{n}=50$, age $=25.3 \pm 1.5 \mathrm{yrs})$. The subjects fulfilled the bullying questionnaire, five item self-rating scale. Descriptive statistics and Mann-Whitney nonparametric test were used to analyze the data.

Results: Compared to their healthy siblings, the patients were more likely to report that they were bullied (patients: $7.0 \pm 3.5$, siblings: $5.2 \pm 2.0, \mathrm{p}=0.000$ ), but patients also bullied others more (patients: $1.4 \pm 0.8$, siblings: $1.1 \pm 0.4, p=0.02$ ). Comparing the group of patients and controls, we did not find statistically significant difference in any category. The male gender brings higher risk of being physically bullied which has been proven for all examined groups (patients- $\mathrm{p}=0.03$, controls and siblings- $\mathrm{p}=0.00$ ).

Conclusion: Aggressive peer relations possibly contribute to the evolution of psychosis, as they were more prevalent in patients in comparison to their healthy siblings, particularly in males. Improved prevention of bullying and use of treatments against its psychological consequences might be one of the possible methods to ameliorate the course of psychosis.

Key words: Bullying, Psychosis, Mental health, Gender 


\section{Introduction}

The etiology of schizophrenia is based on the interaction between genetic and environmental factors. Nowadays, a variety of environmental risk factors has been tested in relation to psychosis risk. Obstetric complications, childhood trauma, bullying, recent stressful events, etc. are becoming important candidates for further evaluation in this domain [1].

To become recognized as a risk factor, one exposure should be more frequent in future patients in comparison to their relatives, who share familiar risk to a certain extent. Literature shows that psychosis cases were approximately twice as likely to report aggressive peer relations when compared to controls [2]. In addition, recent analyses yielded that bullying was the most strongly associated with the presence of concurrent persecutory ideation and hallucinations [3]. This finding could be explained from a perspective of cognitive neuroscience, hypothesizing that dysfunctional appraisals about self and others, that appears as a result of bullying (abnormal attributions of others' intentions, hostility, negative self-esteem, external locus of control, etc), could be related to the onset and maintenance of psychotic phenomena.

Bullying includes physical and verbal attacks or aggression (kicking, pushing, name-calling - direct bullying) and also indirect aggression such as ignoring and gossiping (indirect bullying) which often rely on a third party [4].

The studies on experience of being bullied among adolescents and its relation to gender found strong evidence that the bullying was directly related to sex. Recently published research which analyzed bullying, aggression and sex [5] showed that the percentages of being bullied and bullying others were significantly higher for boys. Present literature has many data showing that boys spend more time with boys in physical activities, while girls tend to spend more of their time socializing with other girls. So, one of the most consistent research findings is that boys are more likely to both bully and be bullied than girls. However, in the UK sample [2] a larger proportion of women in the first psychotic episode was bullied compared to men and the effect of bullying was estimated to be stronger in women. One possible explanation for a differential gender outcome following the experience of peer aggression is that girls are more prone to develop internalizing difficulties, whereas boys tend to respond by exhibiting externalizing behavior.

To our best knowledge, the literature on bullying in relation to psychosis risk in our region is rare, if any. Therefore, the aim of this research was to focus on sample from Belgrade and surroundings, which consisted of patients with psychosis, their healthy siblings and controls, in order to compare exposure to bullying between the groups and to analyze if gender differences regarding bullying Siblings are genetically at higher-than-average risk for psychotic disorder (5-10 fold) [6]. However, a design based on two siblings discordant for the illness effectively controls for a range of unobserved and unmeasured confounding variables given that siblings share a range of developmental and also environmental conditions [7]. If future patients had different levels of bullying exposure in comparison to their healthy siblings and controls, aggressive peer relations could be considered as a highly specific environmental risk factor. On the other hand, if patients had the same exposition as the general population but their siblings differs significantly, such finding might suggest that certain protective factors prevent the unaffected sibling from developing the illness (resilience), or that selection bias operated during the inclusion of affected families.

\section{Materials and methods}

In this cross-sectional study we evaluated the Serbian sample of schizophrenia spectrum patients-P ( $\mathrm{n}=$ $52)$, their healthy siblings-HS $(n=55)$ and controls- $C(n$ $=50$ ). Patients and healthy siblings were included from a larger "European Network of Schizophrenia Networks for the Study of Gene-Environment Interactions (EUGEI)" sample [8].

All subjects originated from urban and suburban municipalities of Belgrade and surroundings. . Inclusion criteria for all participants were: age $\geq 18$ years, no recent history of alcohol or drug abuse, being able and willing to participate. Patients had diagnosis of psychotic disorder (schizophrenia spectrum disorders F 20-29, ICD X) as assessed by the Mini International Neuropsychiatric Interview (version 5.0.0.) [9] by specialist in psychiatry, with illness duration up to 10 years. At the time of evaluation, patients were remitted, which was confirmed by the GAF (The Global Assessment of Functioning Scale) [10] score $>40$. Unaffected siblings of schizophrenia patients and controls had no history of psychiatric disorders. Healthy controls were included on the basis of age (18-35 yrs old) and willing to participate and fulfill the sociodemographic and bullying questionnaires. The study was approved by the Ethics Committee of the School of Medicine, University of Belgrade.

\section{Methods}

The assessment of socio-demography was performed using the short questionnaire designed to collect data regarding age, sex, and education. To evaluate bullying, we used a self-rating scale - the Amended Bullying Questionnaire $[11,12]$, adapted for the purposes of the EU-GEI Network studying Gene-Environment In- 
teractions in Schizophrenia. The questionnaire assessed the acts of bullying by peers (emotional, psychological or physical violence) inflicted on the subject before the age of 17. In the first four items (of the scale adapted to 5 -items), the questions assessed the frequency and intensity of bullying from another child/teenager in form of being called offensive names, being intimidated or humiliated by others, being ignored, excluded from the group or being physically attacked (pushed, kicked, punched) etc. The first question (Bull1) asked whether the person was ever bullied by another child, the second one (Bull2) asked about being physically hurt, the third (Bull3) about being emotionally hurt and the fourth (Bull4) asked about the intensity of bullying- whether it happen often and how disturbing it was. The fifth one (Bull5) asked about bullying another child/teenager (i.e. being a bully). In addition, we computed two composite variables - Bull total (the sum of Bull 1-4 items) and Bull int (Bull1 multiplied by Bull4 item) to focus additionally on the overall intensity of the examined phenomenon.

Statistical analyses

We used descriptive statistics for the analisis of socio-demographic data and Mann-Whitney nonparametric test for the assessment of between-group differences in bullying exposure and gender.

\section{Results}

The sample comprised of patients diagnosed with schizophrenia $(\mathrm{n}=52$, age $=29.3 \pm 5.9 \mathrm{yrs}$; in remission $)$, their healthy siblings $(\mathrm{n}=55$, age $=28.6 \pm 6.8 \mathrm{yrs})$ and controls ( $\mathrm{n}=50$, age $=25.3 \pm 1.5 \mathrm{yrs})$. The sample characteristics are presented in Table $\mathbf{1 .}$

Compared to their healthy siblings, the patients were more likely to report that they were bullied (patients: $7.0 \pm 3.5$, siblings: $5.2 \pm 2.0, p=0.00$ ), regarding all categories except emotional bullying (see Graph 1 and Table 2). Patients had more psychical hurt (patients: 1.4 \pm 0.7 , siblings: $1.2 \pm 0.4, \mathrm{p}=0.04$ ) and more intensive attacks (patients: $1.7 \pm 0.9$, siblings: $1.2 \pm 0.5, \mathrm{p}=0.01$ ) than their siblings, but they also reported that they bullied others (perpetrated) more than their healthy siblings (patients: $1.4 \pm 0.8$, siblings: $1.1 \pm 0.4, \mathrm{p}=0.02$ ).

Comparing the group of patients and controls, we did not find statistically significant difference in any bullying category (Table 2). However, the higher ratio of bullying was shown in the group of controls when it was compared to group of siblings (controls: $6.2 \pm 2.6$, siblings: $5.2 \pm 2.0, \mathrm{p}=0.01$ ). Physical (controls: $1.4 \pm 0.6$, siblings: $1.2 \pm 0.4, \mathrm{p}=0.05$ ) and emotional (controls: 1.6 \pm 0.8 , siblings: $1.3 \pm 0.7, \mathrm{p}=0.00$ ) bullying were more in- tensive (controls: $1.5 \pm 0.7$, siblings: $1.2 \pm 0.5, \mathrm{p}=0.05$ ) in the group of controls than in the group of healthy siblings (Graph 1, Table 2), but there wasn't significant difference in category of bullying.

Table 1. The sample characteristics

\begin{tabular}{|l|l|c|c|}
\hline \multicolumn{2}{|c|}{} & $\mathrm{N}$ & Mean \pm SD/ N(\%) \\
\hline \multirow{4}{*}{$\begin{array}{c}\text { Gender } \\
\text { (male \%) }\end{array}$} & Patient & 52 & 71.1 \\
\cline { 2 - 4 } & Healthy sibling & 55 & 67.3 \\
\cline { 2 - 4 } & Control & 50 & 66.0 \\
\cline { 2 - 4 } & Total & 157 & 66.9 \\
\hline \multirow{4}{*}{ Age } & Patient & 52 & $29.3 \pm 0.6$ \\
\cline { 2 - 4 } & Healthy sibling & 55 & $28.6 \pm 0.7$ \\
\cline { 2 - 4 } & Control & 50 & $25.3 \pm 1.5$ \\
\cline { 2 - 4 } & Total & 157 & $27.8 \pm 5.6$ \\
\hline \multirow{3}{*}{\begin{tabular}{l} 
Years of \\
\cline { 2 - 4 }
\end{tabular}} & Patient & 52 & $12.5 \pm 2.1$ \\
\cline { 2 - 4 } & Healthy sibling & 55 & $13.4 \pm 2.6$ \\
\cline { 2 - 4 } & Control & 50 & $14.0 \pm 0.0$ \\
\cline { 2 - 4 } & Total & 157 & $13.3 \pm 2.0$ \\
\hline
\end{tabular}

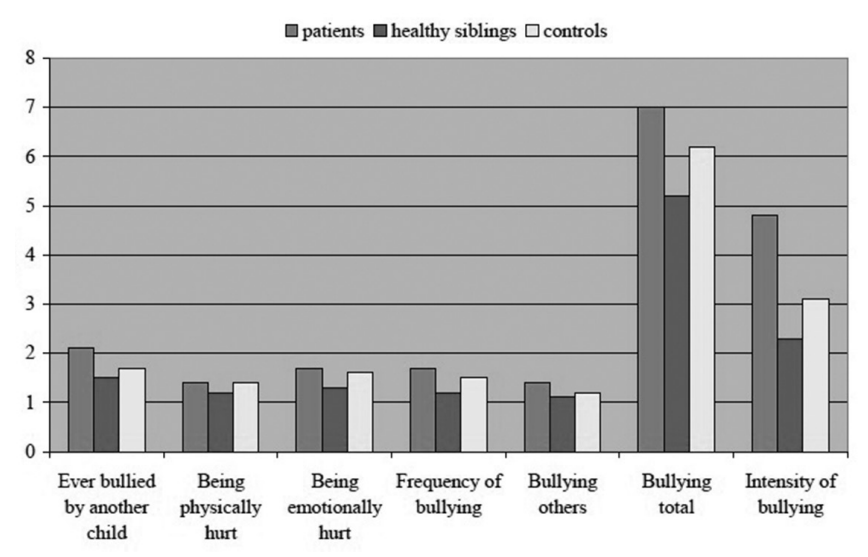

Graph 1. Results related to bullying victimization

Table 2. Between-group differences in bullying patterns (Mann-Whitney test)

\begin{tabular}{|l|l|l|l|}
\hline Variable & $\begin{array}{l}\text { Patients } v s \\
\text { Siblings }\end{array}$ & $\begin{array}{l}\text { Patients vs } \\
\text { Controls }\end{array}$ & $\begin{array}{l}\text { Siblings } v s \\
\text { Controls }\end{array}$ \\
\hline $\begin{array}{l}\text { Ever bullied by } \\
\text { another child }\end{array}$ & $-2.64(0.01)^{\star}$ & $-1.09(0.28)$ & $-1.90(0.06)$ \\
\hline $\begin{array}{l}\text { Being physically } \\
\text { hurt }\end{array}$ & $-2.06(0.04)^{\star}$ & $-0.13(0.90)$ & $-1.94(0.05)^{\star}$ \\
\hline $\begin{array}{l}\text { Being emotionally } \\
\text { hurt }\end{array}$ & $-1.72(0.09)$ & $-1.27(0.20)$ & $-3.31(0.00)^{\star}$ \\
\hline $\begin{array}{l}\text { Frequency of } \\
\text { bullying }\end{array}$ & $-2.61(0.01)^{\star}$ & $-0.79(0.43)$ & $-1.95(0.05)^{\star}$ \\
\hline $\begin{array}{l}\text { Bullying others } \\
\text { Bullying total }\end{array}$ & $-2.61(0.01)^{\star}$ & $-1.45(0.15)$ & $-0.95(0.34)$ \\
\hline $\begin{array}{l}\text { Intensity of } \\
\text { Bullying }\end{array}$ & $-2.65(0.01)^{\star}$ & $-0.92(0.36)$ & $-1.96(0.05)^{\star}$ \\
\hline
\end{tabular}

Note: results are presented as $\mathrm{Z}(\mathrm{p})$, $\mathrm{p}$ values $<0.05$ were considered statistically significant 
Regarding the gender differences in bullying, it was shown that male gender increased the likelihood of being physically bullied, the finding which was evident both in the group of patients $(\mathrm{p}=0.03)$ and the group of controls and siblings $(\mathrm{p}=0.00)$ (see Table 3 ). Considering being bullied otherwise, no significant differences between males and females were shown. However, regarding bullying others, in the groups of healthy participants (siblings and controls) male gender was more likely to do so $(p=0.05)$, while in the group of patients it was equally distributed between the sexes.

Table 3. Sex differences in bullying

\begin{tabular}{|l|l|l|}
\hline \multirow{2}{*}{ Variable } & \multicolumn{1}{|l|}{ Patients } & \multicolumn{1}{|l|}{$\begin{array}{l}\text { Controls and } \\
\text { Siblings }\end{array}$} \\
\cline { 2 - 3 } & \multicolumn{2}{|c|}{ Male vs Female } \\
\hline Ever bullied by another child & $-0.39(0.70)$ & $-1.49(0.14)$ \\
\hline Being physically hurt & $-2.20(0.03)^{\star}$ & $-4.19(0.00)^{\star}$ \\
\hline Being emotionally hurt & $-0.25(0.80)$ & $-0.01(0.99)$ \\
\hline Frequency of bullying & $-1.23(0.22)$ & $-0.52(0.60)$ \\
\hline Bullying others & $-1.53(0.13)$ & $-1.92(0.05)^{\star}$ \\
\hline Bullying total & $-1.13(0.26)$ & $-1.74(0.08)$ \\
\hline Intensity of Bullying & $-0.77(0.44)$ & $-1.44(0.15)$ \\
\hline
\end{tabular}

Note: results are presented as $\mathrm{Z}(\mathrm{p})$, $\mathrm{p}$ values $<0.05$ were considered statistically significant

\section{Discussion}

The focus of our research was to enlighten the possible impact of bullying to evolution of psychosis by analyzing its incidence relying on recall of the memories, which is one of the methods to evaluate bullying, albeit not as precise as cohort studies and immediate records. Anyhow, we found that bullying was more common among patients but only compared to their healthy siblings, while there wasn't noteworthy difference between patients and controls, which differs our results from the findings of other researches.

Several studies that explored the association between peer aggression in childhood and adult psychiatric diagnoses assumed that bullying contributed to psychiatric illness $[2,13]$. Bullying was a moderate to strong predictor of subclinical delusional ideation and hallucinatory experiences in early adolescence [14], while bullied males were 19 times more likely to be suicidal than their peers without bullying involvement [13]. Evaluating the UK sample, Trotta et al. [2] found that psychosis cases were twice as likely to report bullying when compared to controls. Distinction between our results is the most likely caused by the size of the samples. Since the compari- son of healthy siblings and controls showed higher bullying ratio amongst controls, these results could indicate that either certain protective factors operate in relation to the sibling status (either biological or psycho-social factors) or that selection bias influence the representativeness of the sub-samples. Namely, it is possible that some siblings of schizophrenia patients could have been using a defensive style of answering, which may have lowered the frequency of siblings' exposure to peer aggression in the present study. This phenomenon has been observed in the literature recently [7]. However, similarly to existing data, we can conclude that not only victims, but also peer aggressors themselves, could be at higher risk of psychotic experience, since patients (compared to siblings) were more likely to report that they bullied others, which is congruent with already existing findings $[2,13]$. Copeland et al. [13] in their prospective study found that bullying victims were at higher risk for emotional disorders and suicide, and that bullies were only at risk for antisocial personality disorder, with worst effects for those who were both bullies and victims.

Additionally, in our sample of the Serbian origin we confirmed the world-wide observed phenomena, by showing that more exposure to bullying was associated with male gender, regardless of the examined sub-groups. Our results indicate that boys in our region are at greater risk at least of being physically hurt by another child/ teenager. This finding is in line with the results of Popadic and Plut [15], who included 26,228 pupils of grades 3 through 8 in 50 primary schools across Serbia in 2006, and indicated that in a three-month period, $65.3 \%$ of the pupils stated that they experienced some form of peer violence (the percentage varied by school, between $48 \%$ and $80 \%$ ). Moreover, boys declared themselves as perpetrators of violence somewhat more frequently than girls, and they were somewhat more often exposed to peer and adult violence. On the other hand, in comparison to UK sample evaluated by Trotta et al. [2], who showed that compared to men a larger proportion of women in the first episode psychosis group had been bullied, females with psychosis from our sample did not report more bullying vs. males. The difference between the results might be due to our relatively small sample size, as the UK group included almost 5 times more participants.

Besides bullying, other childhood traumas such as abuse and neglect were recognized as the potential underlying cause of the long term sequelae in the domain of mental functioning [16]. Thus, some of the psychotic symptoms may arise under the influence of all these environmental factors inducing epigenetic changes, in addition to the disease-specific de novo mutations which can partially explain sporadic vs. familiar cases of schizophrenia [17]. 
Future research should focus on possible bidirectional relationship between violence and bullying, to explore its cyclical character and to broaden the knowledge we got of studies so far [18-20]. Are the children who witness domestic and/or any other kind of violence at higher risk to become both aggressors and victims and vice versa - do aggressors or victims end up like perpetrators of domestic/partner violence? The aim is to get to the bottom of abusive behavior, in order to create a specific strategy of prevention.

In order to combat bullying, anti-bullying policies and strategies should be developed in schools, and the first milestone should be creating and training working groups. The fact is that in 2005 an important initiative supported by UNICEF [21] named "Skola bez nasilja - ka sigurnom i podsticajnom okruzenju za decu" has begun, and many schools have accepted the principles on how to improve control in the domain of peer aggression. The program gives members of the school community (teachers, staff, parents, students) practical knowledge on how to prevent and solve problem of violence and aims to increase their awareness and to teach them communication skills on constructively resolving disputes when and if they occur. Evaluation of the program in 2009 showed lower peer aggression in early school age and that students were more willing to report bullying [21]. Experiences from implementation of this program are included in the Ministry of Education Special Protocol on the Protection of the Children and Students from Violence, Abuse and Neglect within the Education System [22].

Not only the school, but the parents, local community and the media also have a great role in raising awareness, creating the climate of zero bullying tolerance and helping children to build resilience $[23,24]$. Today we face great efforts of several professional and amateur groups to implement "Aleksin zakon" (Aleksa's Law), after the tragic death due to the suicide of this 14 year old boy from Nis (Serbia), who was a victim of peer aggression and did not succeed to cope with its dramatic mental and overall health consequences. Interventions against bullying should start early, in a primary school, to prevent long-term serious effects on children's mental health. At the same time, children exposed to bullying who tend to be less assertive and more easily upset than their peers who aren't victimized should be followed carefully and supported continually and professionally in order to minimize immediate risks and future consequences.

\section{Conclusion}

Our research added a new data on the present knowledge of bullying in Serbian population, by including people with psychosis and showing the frequency of their exposure to peer aggression in comparison to unaffected siblings and controls. Bullying possibly contributes to the evolution of psychosis, therefore an improved control of peer aggression and use of the treatments targeting its psychological consequences might be one of the possible methods to ameliorate the course of psychosis. Would individuals vulnerable to psychosis have benefit from these interventions remains an important question which demands the further research, preferably through the cohort studies.

\section{Acknowledgement}

The authors are thanking Tijana Mirjanić, MD (specialist in psychiatry, $\mathrm{PhD}$ student at School of Medicine, University of Belgrade) and Marina Mihaljević, MD (resident in psychiatry, PhD student at School of Medicine, University of Belgrade) who were involved in the patients' and siblings' interviewing and testing procedures.

\section{References}

1. Dean K, Murray RM. Environmental risk factors for psychosis. Dialogues Clin. Neurosci. 2005;7(1):69-80.

2. Trotta A, Di Forti M, Mondelli V, Dazzan P, Pariante C, David A, et al. Prevalence of bullying victimisation amongst first-episode psychosis patients and unaffected controls. Schizophr Res. 2013;150(1):169-75.

3. Catone G, Marwaha S, Kuipers E, Lennox B, Freeman $\mathrm{MD}$, Bebbington $\mathrm{P}$, et al. Bullying victimization and risk of psychotic phenomena: analyses of British national survey data. The Lancet Psychiatry. 2015;2(7):618-624.

4. Eisenberg N, Sadovsky A, Spinrad TL, Fabes RA, Losoya $\mathrm{SH}$, Valiente C, et al. The relations of problem behaviour status to children's negative emotionality, effortful control, and impulsivity: concurrent relations and prediction of change. Dev Psychol. 2005;41(1):193-211.

5. Iossi Silva MA, Pereira B, Mendonca D, Nunes B, Abaido de Oliveira W. The involvement of girls and boys with bullying: an analysis of gender differences. Int. J. Environ. Res. Public Health. 2013;10(12):6820-6831.

6. Kahn RS, Magnus R, Linszen DH, Van Os J, Wiersma D, Bruggeman R, et al. Evidence that familial liability for psychosis is expressed as differential sensitivity to cannabis. Arch Gen Psychiatry. 2011;68(2):138-147.

7. Lataster T, Verweij K, Viechtbauer W; GROUP. Effect of illness expression and liability on familial associations of clinical and subclinical psychosis phenotypes. Acta Psychiatr Scand. 2014;129:44-53.

8. European Network of National Networks studying Gene-Environment Interactions in Schizophrenia (EU$\mathrm{GEI})^{*}$. Identifying gene-environment interactions in schizophrenia: contemporary challenges for integrated, large-scale investigations. Schizophr Bull. 2014;40(4):729736.

9. Sheehan DV, Lecrubier Y, Sheehan KH, Amorim P, Janavs J, Weiller E, et al. The mini-international neuropsychiatric 
interview (M.I.N.I.): the development and validation of a structured diagnostic psychiatric interview for DSM-IV and ICD-10. J Clin Psychiatry. 1988;59 Suppl 20:S22-33.

10. GAF Hall RC. Global assessment of functioning. A modified scale. Psychosomatics. 1995;36(3):267-75.

11. Olweus D. Bullying at School: what we know and what we can do. Cambridge: Blackwell Publishers; 1993.

12. Solberg ME, Olweus D. Prevalence estimation of school bullying with the Olweus Bully/Victim questionnaire. Aggressive Behavior. 2003;29(3):239-268.

13. Copeland WE, Wolke D, Angold A, Costello EJ. Adult psychiatric and suicide outcomes of bullying and being bullied by peers in childhood and adolescence. JAMA Psychiatry. 2013;70(4):419-26.

14. Arseneault L, Cannon M, Fisher HL, Polanczyk G, Moffitt TE, Caspi A. Childhood trauma and children's emerging psychotic symptoms: A genetically sensitive longitudinal cohort study. Am J Psychiatry. 2011;168(1):65-72.

15. Popadic D, Plut D. Nasilje u osnovnim skolama u Srbiji-oblici i ucestalost. Psihologija. 2007;40(2):309-328. Serbian.

16. Pejovic-Milovancevic M, Mitkovic-Voncina M, Lecic-Tosevski D. Past, present, and future steps in child abuse and neglect issues: the Serbian journey. Eur Child Adolesc Psychiatry. 2015;24(1):121-4.

17. Maric NP, Svrakic DM. Why schizophrenia genetics needs epigenetics: a review. Psychiatr Danub. 2012;24(1):2-18.

18. Bauer NS, Herrenkohl TI, Lozano P, Rivara FP, Hill KG, Hawkins JD. Childhood bullying involvement and exposure to intimate partner violence. Pediatrics. 2006;118(2):235-242.

19. Falb KL, McCauley HL, Michele R, Decker MR, Gupta J, Raj A, et al. School bullying perpetration and other childhood risk factors as predictors of adult intimate partner violence perpetration. Arch Pediatr Adolesc Med. 2011;165(10):890-894.

20. Johnson RM, Kotch JB, Catellier DJ, Winsor JR, Dufort V, Hunter W, et al. Adverse behavioral and emotional outcomes from child abuse and witnessed violence. Child Maltreat. 2002;7(3):179-86.

21. Unicef.rs [Internet]. UNICEF- Skola bez nasilja - ka sigurnom i podsticajnom okruzenju za decu; c2011 [cited 2015 Dec 5]. Aviailable from: http://www.unicef.rs/skola-bez-nasilja.html/ .

22. Posebni protokol za zastitu dece i ucenika od nasilja, zlostavljanja i zanemarivanja u obrazovno-vaspitnim ustanovama. Beograd: Ministarstvo prosvete i sporta. (2007). Serbian.

23. Americanhumane.org [Internet]. American humane association: Bulling prevention and intervention; c2013 [cited 2015 Oct 3]. Aviailable from: http://www.americanhumane.org/children/stop-child-abuse/fact-sheets/bullying-prevention-and-intervention.html? referrer=https:// www.google.rs/ .

24. Mariposarespect.org [Internet]. Mariposa country project respect: A community-wide effort to create a safe, trusting environment; c2007-12 [cited 2015 Oct 3]. Aviailable from: http://www.mariposarespect.org/ 